\title{
Impact of Supply Components-4As on Tourism Development: Case of Central Karakoram National Park, Gilgit-Baltistan, Pakistan
}

\author{
Submitted 0710/20, $1^{\text {st }}$ revision 13/01/21, $2^{\text {nd }}$ revision 16/02/21, accepted 20/03/21
Rehmat Karim ${ }^{1}$, Normah Abdul Latip ${ }^{2}$, Azizan Marzuki ${ }^{3}$, Attaullah Shah ${ }^{4}$, Faqeer Muhammad $^{5}$

\begin{abstract}
:
Purpose: This research is aimed to find out tourism supply components known as the 4As. Accommodation, Access, Amenities and Attractions for the tourism development in the Central Karakoram National Park, Gilgit-Baltistan, Pakistan.

Design/Methodology/Approach: To carry out the current study, a total of 509 selfadministered questionnaires were distributed among the tourists to collect the data which was analysed by using SPSS and Partial Least Square (PLS). PLS-SEM was applied to find out the relationship between variables and test the strength of the proposed model.

Findings: The study concludes that two variables have significant impact on tourism development while other two identified with insignificant impact on tourism development in the Central Karakoram National Park, Gilgit-Baltistan Pakistan.

Practical implications: Tourism development is linked with increasing the accommodation, facilities, and advertisement whereas the current study includes all the required components which helps in developing tourism at destination.

Originality/value: The importance of infrastructure development as the basis for the tourism development whereas current research further strengthens this idea by exploring and including more components in it.
\end{abstract}

Keywords: Tourism development, Accommodation, Access, Amenities, Attractions, CKNP.

JEL codes:

Paper type: Research article.

\footnotetext{
${ }^{1}$ Karakoram International University, Gilgit-Baltistan, Pakistan, and Universiti Sains Malaysia, Penang, Malaysia, e-mail: rehmat@kiu.edu.pk;

${ }^{2}$ Universiti Sains Malaysia, Penang, Malaysia.

${ }^{3}$ Universiti Sains Malaysia, Penang, Malaysia.

${ }^{4}$ Karakoram International University, Gilgit-Baltistan, Pakistan.

${ }^{5}$ Karakoram International University, Gilgit-Baltistan, Pakistan.
} 


\section{Introduction}

According to Wijayanti and Dewi (2017) tourism destination development is an integrated approach which stands on four basic pillars (tourism components) which include attractions, accessibility, infrastructure, facilities, host community and integrated communication within and outside the destination. Tourism industry can be endorsed by improving the quality, diversifications and revitalization of tourism products and tourism institutions, the human resource factor, the coordination, integration, and standardization of tourism education.

The tourism components 4As (Accommodation, Access, Amenities and Attractions) are the ones that tourism managers should consider in the development of the destination and ensure that all components are best suited with the quality and requirements of visitors (Haneef, 2017). Cooper (2000), Sugiama, (2013), Sugiama, (2014c) considered the 4As tourism components essential factors for the destination development which also supported by Andrianto and Sugiama, (2016). Tourists always appreciate when destination provides quality accommodation, attraction, and accessibility to the destination resultantly, which improves the tourism development of any region (Hartwell et al., 2016; Mwinuka, 2017). Camilleri (2018) also emphasised on key tourism components, access, accommodation, attractions, and amenities considering the most important factors for tourism development.

Moreover, these components were considered as fundamental requirement which travelers expect from the destinations where tourists intended to travel for various tourism purposes. Reitsame and Sperdin (2017) denoted access and amenities as 'sense-making' and attractions and activities as exploratory attributes, they further argued that if these factors are adequately developed tourists perceive the wellbeing and engage through positive word of mouth about the destination which tourism planners and destination developers must consider. Stylidis, Shani and Belhassen (2017) carried out to test the integrated destination image model where they denoted attractions, amenities, accessibility, and accommodation as cognitive components and found that cognitive components have significant positive effect on destination image model where there they denoted attractions, amenities, accessibility, and accommodation as cognitive components and found that cognitive components had significant positive effect on destinations' image which can ultimately improve the tourism development.

\section{Literature Review}

Hartl (2002) highlighted the importance of 4As of tourism for the destination development, moreover study described the 4As as 'Destination Mix'. Kharel and Khanal (2011) identified tourism components 3As, access, accommodation, and amenities to consider for the destination tourism services. The accommodation is very important and basic component in tourism sector, and it serves as key element to satisfy the tourists' and visitors' stay at the destination (Rahovan, 2013). Accommodation is a mix of many facilities included hotel service, lodges, camp 
sites, home stays, caravans, in addition to bread and breakfast during the stay at destination (Haneef, 2017). Despite the different forms of accommodation provided to the visitors or tourists, hotels become more useable forms in urban settings (Craggs, 2008). Accommodation includes, home stays, lodges, caravans, hotels, guest houses and other, it becomes more beneficial when providers provide additional components e.g., food and beverages in addition to stay (Andrianto and Sugiama, 2016). Jovanović and Ilić, (2016) considers accommodation as "social infrastructure" which include availability of rooms, hotel services, shopping arcades and meeting, incentives, conference, and exhibitions (MICE) facilities that encourages and motivates tourists to visit the destination and ultimately develop the tourism destination. Sharpley (2000) strongly argued the influence of accommodation on tourism development at destination. The study highlighted the importance and significant role of accommodation and emphasized to understand the need of controlled development on accommodation for a sustainable tourism planning and development at the destination.

Access to the destination is one of the key components of tourism to attract more visitors at the destination (Sugiama, 2013; Andrianto, and Sugiama, 2016). According to Grzinic and Saftic (2012) improved accessibly ensures the flow of visitors at the tourists' destination, if the road connectivity is poor at any destination tourists get frustrated. Accessibility as an important component of tourism infrastructure provides basis for tourists to travel which helps in long term growth and development of tourism destination (Jovanović and Ilić, 2016). Several studies acknowledged the role of transport for easy access to desired destination whereas Sorupia (2005) highlighted the negative impacts of over-access to the destination. Study revealed that easy access increases the tourist and day trippers flow to the destination which cases environmental degradation and traffic congestion at the destination, "accessibility can make or break a destination" (Jovanović and Ilić, 2016, p. 1769), the authors argued on the given statement that if over access is provided to the tourists at any destination, it dominates local populous and cases of environmental degradations and overuse of natural resources.

Amenities are the facilities added to the tourists' service to make the tourists comfortable and add value to the overall tourism activities at the destination. Amenities are considered as complementary facilities with accommodation and accessibility which are needed for tourists' satisfaction, amenities can be "tangible and intangible facilities used to obtain pleasure of the visitors at the destination" (Robustin et al., 2018, p. 95). As explained by Mandić, Mrnjavac and Kordić (2018) amenities make the tourism service enjoyable, reliable, and sustainable which widely includes all the physical and mental related infrastructure facilities.

Attractions are important elements of any destination which motivate tourists to visit destination and fulfil their recreational demand (Richards and Wilson, 2006; Haneef, 2017). Attractions can be any form which fulfil the utility of tourists or visitors at the destination, these included, culture, mountains, community, scenic beauty, gastronomy and many others (Andrianto, and Sugiama, 2016). Dwyer and 
Kim (2003) indicate the quality of physical attractions are evaluated through identifying the tourists' satisfaction and motivation to visit the destination and its development (Law and Lo, 2016). Camilleri (2018, p. 24) argued that tourists seldom travel to any place just for staying at any particular accommodation facility rather tourists travel to any destination to see the key attractions, enjoy and do the unique experiences so the any particular feature of the destination which motivates a traveller or tourists towards it termed as "attraction" which can include; "natural wonders, man-made attractions, special events, cultural or historic sites, arts and crafts, sport, music or dance, unusual or unique flora and fauna and night life". Vengesayi (2009) attempted to find out the association between attractiveness of the destination and attractions by extending the previous studies (Echtner and Ritchie, 1993; Hu and Ritchie 1993; Meinung, 1995; Lee, 2001; Klenosky, 2002) to rank the attributes of attractiveness and revealed that attractions are the key focus of destination development along with the predictions people and facilities. Marahatta and Keshtri (2012, p. 47) recommended the tourism attraction as basic element of tourism development and defined as "anything that creates a desire in any person to travel in a specific tourist destination". They denoted the attractions with the word 'locale' for local holiday destinations or attraction which are being offered to the tourists.

\section{Research Design and Methodology}

This research design is intended to assess the perspectives about tourism development analysis in the Central Karakoram National Park, in the opinion of foreign and domestic tourists. Therefore, quantitative research method with the background of cross-sectional method is used in this research. Probability sampling method was used by employing simple random sampling (SRS) approach. Simple random sampling is a basic sampling technique; group of samples were selected from large number of tourists travelling to the Central Karakoram National Park. The Central Karakoram National Park is scattered around 10000 sq. km which covers the boundaries of five districts and there are multiple entry points from various locations.

Thus, simple random sampling is fair way to approach the sample group. By using this method researcher ensures that the equal chance is given to the sample units. Self-administered questionnaire was used as key research instrument to collect the data from tourist (foreign and domestic). The instrument was thoroughly processed by checking the reliability, internal consistency, and validity as it is one of the requirements of survey research. As this thesis aims to investigate the relationship of tourism development regarding supply components of tourism (4As: accommodation, access, amenities, and attractions).

Therefore, SPSS-21 and Smart PLS program3 packages were used to process and analyse the attained questionnaires survey-based data in the Central Karakoram National Park, Gilgit-Baltistan, Pakistan. Partial Least Square Structural Equation Modelling (PLS-SEM) was used to evaluate the variables set for the study. PLS- 
SEM can be helpful for formative as well as reflective variables to find the causeand-effect relationship. It is considered as nonparametric method; therefore, PLSSEM is commonly used to assess variance-based research models in the field of social sciences (Hair et al., 2012; Hussain et al., 2018).

Figure 1. Research Framework

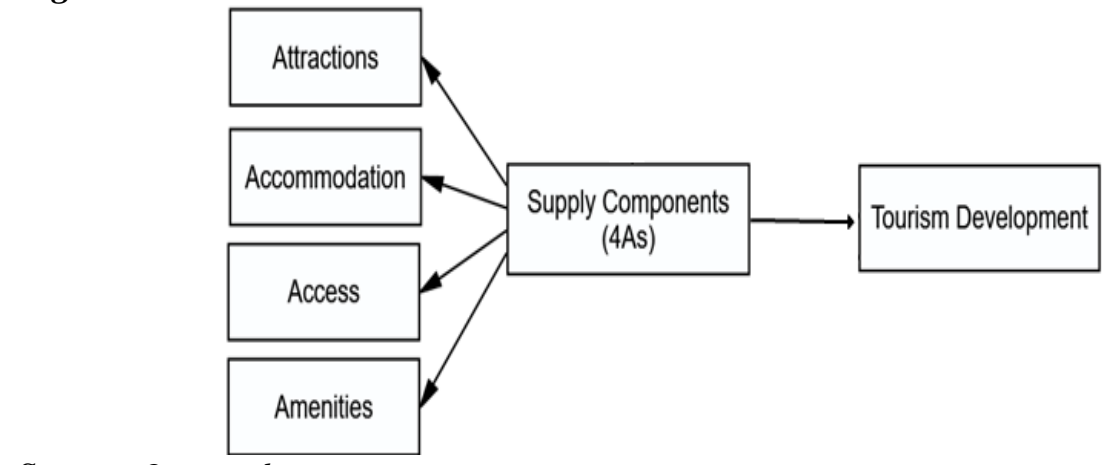

Source: Own study.

\section{Findings and Discussions}

This study attempted to find out the relationship of various supply components factors towards tourism development in the mountain areas of northern Pakistan. By distributing 509 questionnaires among the foreign and domestics tourists visited CKNP this thesis observed the following results in majority: age Group; 25-44 years (70\%), education level; diploma holders (36\%), gender; male (68\%), nationality (foreign tourists); Japanese (10\%), purpose of visit; adventure (49\%), type of accommodation used; campsite (52\%), average length of stay; 7 days (46\%), years of mountain tourism experience; more than 10 years (42\%), type of tourists; trekkers (41\%), travel party size; 4-6 persons (35\%), status of local support employed; porters only (41\%), reason for the visit; holiday (67\%), mode of transport used in CKNP; private jeep (73\%), mode of travel; An inclusive tour package (73\%), frequency of visit to CKNP; first time visit (40\%), sources of information about CKNP; social media (30\%), rating of holidays in CKNP; very good (44\%), willingness to visit again; Yes, in future (54\%) and familiarity with CKNP; No $(58 \%)$.

Moreover, concerns pertaining to the issues at destination, majority of tourists were not concerned about crime (99\%), health (95\%), political instability (100\%), hospitality of people $(100 \%)$, sectarian conflicts $(96 \%)$ and quality of attractions $(100 \%)$ whereas majority of respondents were very much concerned about transportation and communication (66\%), shopping facilities (39\%) and quality of accommodation $(52 \%)$.

Majority of tourists suggested to develop and improve transport (70\%), marketing (opening more booking offices and information dissemination centers) (94\%), finding new visitors generating countries (69\%), develop and improve 
communication (82\%), accommodation facilities at existing price (91\%) operate direct international flights to Gilgit-Baltistan $(65 \%)$ is highly important to increase tourists' arrivals to the Central Karakoram National Park area.

\subsection{Assessment of Measurement Model}

According to Carneiro et al. (2007) measurement model is used to find out the relationship between measured variables to latent variables whereas structural model is to relate the latent variables with one another. The assessment was performed to evaluate the unidimensional, reliability and validations though CFA procedures to ensure the required reliability before proceeding to final model development. The final measurement model was assessed by using various fit indices Quality criteria is required to measure the importance and descriptive strength of measurement model; various quality criteria analyses are conducted to measure the model in this study. To find out the level and trend of relationship between the variables and various factors in the research, a correlation analysis was carried out.

The basis of identifying the strength of affiliation among the variables was application of "structural model". Various required analyses were carried out by using SPSS 21.0 and Smart-PLS-3. Both EFA and PCA are run via programs like SPSS, which calls this approach data reduction, with the advent of structural equation modelling (SEM) tools, such as PLS, an argument for not purifying measures and treating an instrument more holistically has been made (MacCallum and Austin, 2000; Straub et al., 2004), but there is no clear resolution about whether measurement error should be modelled and accounted for or simply eliminated.

In contrast to EFA, PLS performs a Confirmatory Factor Analysis (CFA) (Gefen and Straub, 2005 p. 93). As suggested by Zainudin (2012) measurement model was carried out with Confirmatory Factor Analysis (CFA), recommended to remove the items with lower factor loadings which do not meet the minimum threshold.

Two questions were dropped in the accommodation construct due to lower loadings scores whereas five questions remained for further process. Highest loading score was recorded for "accom_2, cleanliness of hotel/motel/guest house/campsite" (0.905), three questions were dropped from access construct and four were used for further analysis. Highest lodgings were obtained by "access_7, availability of toilets on trekking/mountaineering/hiking routes" $(0.830)$.

For the amenities construct, two questions were dropped, and five questions were remained where the highest loading was attained by "role of information centres, amaneties_4" (0.851) and three questions were dropped and fours were 
used for the analysis in the attractions construct, highest loadings was obtained by "landscapes of CKNP, attractions_1" (0.802).

Thus, the aim of this model is to find the relationship between marketing mix, tourism supply components and tourism development in the Central Karakoram National Park.

\subsection{Reliability Assessment for the Measurement Model}

To test the measurement model in this study, reliability and validity analyses were carried out which are shown in the Table 1. Results show that Cronbach's alpha, Composite Reliability (CR) and Average Variance Extracted (AVE) are above than the threshold values; "Cronbach's $\alpha$ :> 0.7"; (Nunnally and Bernstein, 1978; "> 0.4 (Peter, 1997)", "Composite Reliability :> 0.7” (Hulland, 1999), “Average Variance Extracted (AVE): $>0.5$ ” (Khoshkam, 2013, p. 118).

\subsection{Internal Reliability}

Cronbach's alpha values of key constructs of the tourism supply components were found as; 'accommodation' 0.891 , followed by 'access' 0.818 , 'amanitas' 0.865 and 'attractions' 0.952 . From the results shown for internal reliability, it can be safe to claim that questionnaire used for this study is internally consistent and suitable for the analysis.

\subsection{Composite Reliability}

According to Morrison et al. (2017) "composite reliability can be viewed as analogous of Cronbach's alpha coefficient" which indicates the internal consistency and authenticity of the latent variables. As recommended by Shaw and Shiu (2003) "the threshold value for composite reliability is $\geq 0.60$ " and acceptable values are 0.70 . This study achieved the required acceptable values of composite reliability for its measurement model with the attained tested values as; 'accommodation' 0.920 , followed by 'access' 0.878 , 'amenities' 0.901 and 'attractions' 0.965 .

\subsection{Average Variance Extracted (AVE)}

The study obtained the required acceptable values " $>.50$ " of Average Variance Extracted (AVE) for each construct in the measurement model with the attained tested values as; 'accommodation' 0.699, followed by 'access' 0.644, 'amenities' 0.647 and 'attractions' 0.875 .

\subsection{Convergent Validity}

According to Hair et al. (2014) convergent validity is the "extent to which indicators of a specific construct converge or share high proportion of variance 
in common". To evaluate the level of convergent validity, three techniques are used as highlighted by Hair et al. (2014), reliability, factor loadings and Average Variance Extracted (AVE). Kline (2011) recommends that AVE value 0.5 or greater is acceptable threshold for adequate convergent validity. In this study 4As of tourism supply components and tourism development are assessed by using the recommended criteria. Estimated values of each construct in this study meets the rule of thumb and scored more than 0.5 for each construct. The composite reliability values are also given in Table 1 showing that the obtained values for each construct are greater than the threshold minimum score of 0.7 with the range of 0.873 to 0.965 .

Table 1. Results of Quality Criteria

Source: Own study.

\begin{tabular}{|l|l|l|l|}
\hline Construct & $\begin{array}{l}\text { Cronbach's } \\
\text { Alpha }\end{array}$ & $\begin{array}{l}\text { Composite } \\
\text { Reliability }\end{array}$ & $\begin{array}{l}\text { Average Variance } \\
\text { Extracted (AVE) }\end{array}$ \\
\hline Access & 0.818 & 0.878 & 0.644 \\
\hline Accommodation & 0.891 & 0.920 & 0.699 \\
\hline Amenities & 0.865 & 0.901 & 0.647 \\
\hline Attractions & 0.952 & 0.965 & 0.875 \\
\hline Tourism Development & - & - & - \\
\hline
\end{tabular}

\subsection{Structural Model Evaluation}

Once the validity and reliability of measurement model get finalised then next steps start to evaluate the structural model outputs. "The coefficient of determination $\left(\mathrm{R}^{2}\right)$, Path coefficient ( $b$ value), and T-statistic value, Effect size $\left(f^{2}\right)$, the Predictive relevance of the model $\left(\mathrm{Q}^{2}\right)$, and Goodness-of-Fit (GOF) index" (Hussain et al., 2018, p. 11) are the vital criterions to assess the structural model. According to Fornell and Bookstein (1982) " $R^{2}$ test for dependent variables, the predictive relevance of the model $\left(Q^{2)}\right.$ and effect size $\left(f^{2}\right)$ " (Khoshkam, 2013, p. 123) scores describes the effeteness of the model used where the values of " $\mathrm{R} 2>0.75$ " are substantial, "0.50" is mild and " 0.26 " is frail (Hussain et al., 2018, p. 11).

The value of variance of endogenous construct obtained for this study shown as $\mathrm{R} 2=.346$ predicts a moderate effect of four exogenous variables; A1accommodation, A2-Access, A3-Amenities, and A4-Attrctaions) on endogenous vatable (Tourism Development), $34.60 \%$ of change in tourism development occurs due the given variables.

The blindfolding results highlighted below (Table 3) shows acceptable values of Q2 which are greater than the threshold value zero (Khoshkam, 2013) whereas Goodness of Fit (GOF) index is also moderately acceptable with the value of .346, concluding that the model is having suitable predictive relevance in this study. Moreover, obtained value 0.075 of SRMR (saturated and estimated) indicate that lie below the thresholds value of $<0.08$ ( $\mathrm{Hu}$ and Bentler, 1999; Cheah et al., 2018) (Table 2). 
Table 2. Model fit

Source: Own study.

\begin{tabular}{|l|l|}
\hline SRMR & 0.075 \\
\hline d_ULS & 4.630 \\
\hline d_G & 3.583 \\
\hline Chi-Square & $7,644.858$ \\
\hline NFI & 0.619 \\
\hline
\end{tabular}

Table 3. Construct Cross-validated Communality Test

Source: Own study.

\begin{tabular}{|l|l|l|}
\hline & $\mathrm{Q}^{2}$ & $\mathrm{R}^{2}$ \\
\hline Access & 0.397 & - \\
\hline Accommodation & 0.524 & - \\
\hline Amenities & 0.453 & - \\
\hline Attractions & 0.713 & - \\
\hline Tourism Development & 0.503 & 0.346 \\
\hline
\end{tabular}

\subsection{Overall Final Measurement Model}

The bootstrapping results under the variables of tourism supply components (4As) two variable access and attractions were found significant with the obtained values $\beta=-0.290$, standard deviation $=0.078$, $\mathrm{t}$-statistic $=3.722$ and $\mathrm{p}$ value $=<0.05$ and values $\beta=-0.119$, standard deviation $=0.037$, t-statistic $=$ 3.199 and $p$-value $=<0.05$ respectively. This shows that access and attractions play pivotal role in the development of tourism in the Central Karakorum National Park. In contrast the results of other two variables of supply components accommodation and amenities were found insignificant in relation with tourism development in CKNP as per given results $\beta=-0.025$, standard deviation $=0.069$, $\mathrm{t}$-statistic $=0.364$ and $\mathrm{p}$-value $=>0.05$ and values $\beta=-0.012$, standard deviation $=0.085$, t-statistic $=0.144$ and $\mathrm{p}$-value $=>0.05$ respectively. Similar results were found by Robustin et al. (2018) against the investigation carried out tested the effect of tourist attraction, amenities, accommodation, and accessibility on tourists' loyalty showed that $65.6 \%$ effect by access and attractions whereas remaining $35.4 \%$ is caused by other factors such as accommodation and amenities.

\subsection{Hypothesis Testing}

This study model has four (4) latent constructs, accommodation, access, amenities, and attractions. These constructs provide hypotheses to be tested for deducing the empirical association between variables. To test the hypotheses of the study Structural Equation Modelling (SEM) was applied by using Smart PLS-3. Four direct hypotheses through path analysis were carried out on observed variables in this research with following paths;

H1: There is significant effect of quality of accommodation on tourism development in the CKNP. 
H2: $\quad$ There is significant effect of quality of access on tourism development in the CKNP.

H3: There is significant effect of amenities on tourism development in the CKNP.

H4: There is significant effect of quality of attractions on tourism development in the CKNP.

In addition to testing the hypotheses, the effect size of the marketing mix and tourism supply components were also computed as part of the analysis to validate the objectivity of the study in terms of finding the relationship between the variables. The $\mathrm{f}^{2}$ is the level of effect of the latent construct of exogenous variables on latent construct of endogenous variables, meaning that if any construct from exogenous variables is removed whether its effect on endogenous variables. According to Cohen (1988), " $\mathrm{f}^{2}$ values of $0.02,0.15$, and 0.35 considered to be small, medium and signify respectively" (Hussain et al., 2018), given the results in Table 4 all the effects are found non-significant in this study.

Table 4. Path Coefficient and Effect Size $\left(f^{2}\right)$ Results

\begin{tabular}{|l|l|l|}
\hline & path coefficient $(\boldsymbol{\beta})$ & $\mathbf{f}^{\mathbf{2}}$ \\
\hline Access -----> Tourism Development & -0.290 & 0.021 \\
\hline Accommodation ----> Tourism Development & -0.025 & 0.000 \\
\hline Amenities ---->> Tourism Development & -0.012 & 0.000 \\
\hline Attractions -----> Tourism Development & -0.119 & 0.020 \\
\hline
\end{tabular}

Source: Own study.

The given results indicated that the hypotheses $\mathrm{H} 1$ and $\mathrm{H} 3$ are statistically significant and in the hypothesized relationship in the study. The $\beta$ values and $P$ values of hypotheses are: $\mathrm{H} 1 ; \beta=-0.197, \mathrm{P}=0.003$ and $\mathrm{H} 3 ; \beta=-0.139, \mathrm{P}=$ 0.001 whereas hypotheses $\mathrm{H} 2$ and $\mathrm{H} 4$ are not statistically significant as these were hypothesized in the research. The $\beta$ values and $\mathrm{P}$ values of hypotheses are: $\mathrm{H} 2 ; \beta=0.008, \mathrm{P}=0.904, \mathrm{H} 4 ; \beta=-0.051, \mathrm{P}=0.098$. Based on the statistical evidence, it was revealed quality of access and attractions plays role in tourism development. The summary of hypotheses shown in the Table 5 highlighted that two hypotheses were found significant, and two hypotheses were not supported.

Table 5. Hypothesis Results

\begin{tabular}{|l|l|l|l|l|l|l|}
\hline Path & path coefficient $(\beta)$ & SD & t. stats & P-value & Results & Decision \\
\hline $\begin{array}{l}\text { Attractions >> Tourism } \\
\text { Development }\end{array}$ & -0.119 & 0.037 & 3.199 & $0.001 * *$ & significant & supported \\
\hline $\begin{array}{l}\text { Amenities >> Tourism } \\
\text { Development }\end{array}$ & -0.012 & 0.085 & 0.144 & 0.886 & $\begin{array}{l}\text { Not } \\
\text { significant }\end{array}$ & $\begin{array}{l}\text { Not } \\
\text { supported }\end{array}$ \\
\hline $\begin{array}{l}\text { Access >> Tourism } \\
\text { Development }\end{array}$ & -0.290 & 0.078 & 3.722 & $0.000 * *$ & significant & supported \\
\hline $\begin{array}{l}\text { Accommodation } \\
\text { Tourism Development }\end{array}$ & -0.025 & 0.069 & 0.364 & 0.716 & $\begin{array}{l}\text { Not } \\
\text { significant }\end{array}$ & $\begin{array}{l}\text { Not } \\
\text { supported }\end{array}$ \\
\hline
\end{tabular}

Source: Own study. 


\section{Conclusions}

To explore the relations of tourism components, this study conceptualized a model consisting of various indicators as; Tourism Components 4As (Accommodation, Access, Amenities and Attractions) toward the tourism development in the Central Karakoram National Park. By using PLS method model was tested to answer the research questions and hypotheses formulated in the given research model. Objectives were set out to assess the relationship between quality of tourism components; 4As tourism model (accommodation, access, amenities, and accessibility) and tourism development.

Four research questions were created for proceed which are as follows: impact tourism development in CKNP?

RQ1: how the quality of accommodation

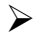

RQ2: does accessibility is appropriate to visit Central Karakoram National Park which impact the tourism development? impact tourism development?

RQ3: are amenities provided in the CKNP tourism development in CKNP?

RQ4: how quality of attractions impacts the

Four hypotheses were developed to authenticate the results attained from level of significance $\mathrm{p}$ values for the entire variables included in $4 \mathrm{As}$ of tourism components. Rahman et al. (2019), his study attempted to find out relationship of accommodations, convenient accessibility to the destination, provision of amenities, all types of attractions with tourists' satisfaction. The study described each variable in detail considering them as important elements of service marketing and development. Liu et al. (2019) highlighted the importance of accessibility and marketing in tourism development of destination. The study argued that since tourists come from different cultures and backgrounds; some travel from within the country (domestic tourists) whereas some travel as foreign tourists (inbound tourists) from different countries, therefore, they perceive the level of tourism development at destination in different ways.

Study carries out the relationship between how marketing can promote tourism development at destination regarding domestic and foreign tourists, moreover, it also attempts to find out to assess the impact of transportation (railways and highways) on tourism development regarding domestic and foreign tourists. Kahn and Vein (2012) conceptualized the model to study the "factors influencing tourism development in Vietnam" which explains the relationship of various components e.g., tourism infrastructure, travelling resources (accessibility), preparedness of tourism attraction, internal and external factors which are important to be considered in the tourism development and available tourism potentials at destination. 
The theoretical model presents the empirical relationship, further, it reveals that there is strong positive effect of accommodation development on tourism demand. It also stressed on relationship of pricing strategy and tourism natural attractions and revealed that these variables have strong effect on tourism development. Results showed that access and attractions showed a significant relationship with tourism development which is supported other research and models developed by above mentioned researcher whereas there is a contrast finding of accommodation and amenities which showed an insignificant impact on tourism development in the Central Karakoram National Park.

Two arguments may come up in this situation that area:

since CKNP is an adventure destination and that's why accommodation for tourists seems not that important as most of the tourists stay in camping sites,

since more tourists stay outside the established accommodation therefore, tourists do not expect more amenities in the national park.

Hence the relationship of accommodation and amenities with tourism development is insignificant.

\section{References:}

Adrianto, T., Sugiama, A.G. 2016. The Analysis of Potential 4A's Tourism Component in the Selasari Rural Tourism, Pangandaran, West JavaAsia Tourism Forum 2016 The 12th Biennial Conference of Hospitality and Tourism Industry in Asia (ATF$16)$.

Camilleri, M.A. 2018. The Tourism Industry: An Overview. In Travel Marketing, Tourism Economics, and the Airline Product. Chapter 1, 3-27. Cham: Springer Nature.

Carneiro, J.M.T., Silva, J.F., Rocha, A., Dib, L.A.R. 2007. Building a Better Measure of Business Performance. RAC-Eletrônica, 1(2), 114-135.

Cooper, D., Schindler, P. 2008. Business research methods (10th ed.). New York, McGraw Hill/Irwin.

Craggs, R. 2008. Tourism and urban regeneration: an analysis of visitor perception, behaviour and experience at the Quays in Salford. Doctoral Thesis. University of Salford. doi:10.21427/D7232M.

Dwyer, L., Kim, C. 2003. Destination competitiveness and bilateral tourism flows between Australia and Korea [online]. Journal of Tourism Studies, Vol. 14, No. 2, 55-67.

Echtner, C., Ritchie, B. 1993. The measurement of destination image: An empirical assessment. Journal of Travel Research, 31(3), 3-13.

Fornell, C., Bookstein, F.L. 1982. Two Structural Equation Models: LISREL and PLS Applied to Consumer Exit-Voice Theory. Journal of Marketing Research, 19(4), 440- 452.

Gefen, D., Straub, D. 2005. A practical guide to factorial validity using PLS-Graph: Tutorial and annotated example Communications of the Association for Information systems, 16 (1), 5.

Grzinic, J., Saftic, D. 2012. Approach to the Development of Destination Management in 
Croatian Tourism (Pristup razvoju destinacijskog menadzmenta u hrvatskom turizmu). Management: Journal of Contemporary Management Issues, 17, 59.

Hair, J.F., Sarstedt, M., Ringle, C.M., Mena, J.A. 2012. An Assessment of the Use of Partial Least Squares Structural Equation Modeling in Marketing Research. J. Acad. Mark. Sci., (40), 414-433.

Hair, J.F., Sarstedt, M., Hopkins, L., Kuppelwieser, V.G. 2014. Partial least squares structural equation modeling (PLS-SEM): An emerging tool in business research. European Business Review, Vol. 26, No. 2, 106-121.

Haneef, S.K. 2017. A Model to Explore the Impacts of Tourism Infrastructure on Destination Image for Effective Tourism Marketing. Doctoral Thesis, School of the Built Environmental, University of Salford, UK.

Hart, A. 2000. Developing Marketing Strategies for tourism Destinations in Peripheral Areas of Europe: The Case of Bornholm. Doctoral Thesis, Centre for Regional and Tourism Research Bournemouth University, Bornholm, Denmark.

Hartwell. H., Fyatt, A., Page. S.W., Ladkin, A., Hemingway, A. 2016. Progress in tourism and destination wellbeing research. Current issues in Tourism, Routledge, London.

Hussain, S., Fangwei, Z., Siddiqi, A.F., Ali, Z., Shabbir, M.S. 2018. Structural Equation Model for Evaluating Factors Affecting Quality of Social Infrastructure Projects. Sustainability, 10(2-25).

$\mathrm{Hu}$, Y., Ritchie, B. 1993. Measuring destination attractiveness: A contextual approach. Journal of Travel Research, 25-34.

Jovanović, S., Ilić, I. 2016. Infrastructure as important determinant of tourism development in the countries of Southeast Europe. ECOFORUM, 5(1), 288-294.

Kharel, B.P., Khanal, S. 2011. Rural Tourism. Kathmandu: Success Foundation.

Khoshkam, M. 2013. Residents' Attitude Towards Impacts from Tourism Development in Anzali Wetland, Iran. PhD. Thesis, Univeristi Sains Malaysia.

Klenosky, D. 2002. The "pull" of tourism destinations: Tourism means-end investigation. Journal of Travel Research, 40, 385-395.

Kline, R.B. 2011. Methodology in the Social Sciences. Principles and practice of structural equation modelling (3rd ed.). Guilford Press.

Law, F.Y., Lo, M.C. 2016. Rural Tourism Destination Competitiveness of Kubah National Park in Sarawak: Tourists' Perspective. Asian Academy of Management Journal, Vol. 21, Supp. 1, 127-148.

Lee, H.C. 2001. Determinants of recreational boater expenditures on trips. Tourism Management, 22(6), 659-667.

MacCallum, R.C., Austin, J.T. 2000. Applications of Structural Equation Modelling in Psychological Research. Annual Review of Psychology, 51(1), 201-226.

Mandić, A., Mrnjavac, Ž., Kordić, L. 2018. Tourism Infrastructure, Recreational Facilities and Tourism Development. Tourism and Hospitality Management, 24(1), 1-22.

Marahatta, D., Kshetri, B.B. 2012. Major Factors Contributing to Tourism in Patihani VDC of Chitwan, Nepal. International Journal of Scientific \& Technology Research, 1(9), 46- 51.

Meinung, A. 1995. Determinants of the attractiveness of tourist destination: In S.F. Witt, L. Moutinho, (Eds.). Tourism marketing and management handbook. Fordshire: Prentice Hall.

Morrison, T.G. Morrison, M.A., McCutcheon, J.M. 2017. Best Practice Recommendations for Using Structural Equation Modelling in Psychological Research. Psychology, (8), 1326-1341.

Mwinuka, O.H. 2017. Reviewing the role of tourism marketing in successful sustainable 
tourist destinations. African Journal of Hospitality, Tourism and Leisure, 6(2), 111.

Reitsamer, B.F., Sperdin, A.B. 2017. Tourist destination perception and well-being: What makes a destination attractive. Journal of Vacation Marketing, 23(1), 55-72.

Rahovan, A.L. 2013. The old hotels of Transylvania: heritage tourist resources. Forum Geografic, 12(1),100-107.

Robustin, T.P., Sularso, R.A., Suroso, I., Yulisetiarini, D. 2018. The Contribution of Tourist Attraction, Accessibility and Amenities in Creating Tourist Loyalty in Indonesia. J. Bus. Econ. Review, 3(4), 92-98.

Richards, G., Wilson, J. 2006. Developing Creativity in Tourist Experiences: A Solution to The Serial Reproduction of Culture? Tourism Management, 27(6), 1209-1223.

Sharpley, R. 2000. The influence of the accommodation sector on tourism development: lessons from Cyprus. Hospitality Management, (19), 275-293.

Shaw, D., Shiu, E. 2003. Ethics in consumer choice: a multivariate modelling approach. European Journal of Marketing, 3710, 1485-1498.

Sorupia, E. 2005. Rethinking the Role of Transportation in Tourism. Proceedings of the Eastern Asia Society for Transportation Studies, Vol. 5, 1767-1777

Stylidis, D., Shani, A., Belhassen, Y. 2017. Testing an integrated destination image model across residents and tourists. Tourism Management, (58), 184-195.

Straub, D., Boudreau, M.C., Gefen, D. 2004. Validation Guidelines for IS Positivist Research. Communications of the Association for Information Systems, 13(24).

Sugiama, A. 2013. Tourism Asset Management: The Effect of Service Quality on Tourist Satisfaction and Loyalty (Manajemen Aset Kepariwisataan: Pelayanan Berkualitas agar Wisatawan Puas dan Loyal), Edisi 1, Guardaya Intimarta, Bandung.

Sugiama, A. 2014c. The Framework of Rural Tourism Development, Business and Economic Seminar. Proceeding, Jenderal A Yani University, Bandung, ISSN:24068942, 404-410.

Vengesayi, S., Mavondo, F.T., Reisinger, Y. 2009. Tourism Destination Attractiveness: Attractions, Facilities and People as Predictors. Tourism Analysis, Vol. 14, 621636.

Wijayanti, A., Dewi, I.J. 2016. Analysis of the Four Pillars of Tourism Development Planning in the Tourism Areas of Kretek, Bantul, Yogyakarta, Indonesia. The 12th Biennial Conference of Hospitality and Tourism Industry in Asia (ATF-16), 154158.

Zainudin, A. 2012. Structural Equation Modelling using AMOS Grapics, 2nd Edition. Shah Alam. Universiti Teknologi MARA Publication Centre. 